\title{
PERBEDAAN HASIL BELAJAR MATEMATIKA MENGGUNAKAN MODEL PEMBELAJARAN TGT, NHT DAN DIRECT INSTRUCTION
}

\author{
Ragil Desi Wulandari ${ }^{1)}$, Tomi Listiawan ${ }^{2)}$, Mugianto $^{3)}$ \\ 1) ragil.desi@stkippgritulungagung.ac.id, ${ }^{2)}$ tomi@ skippgritulungagung.ac.id, \\ ${ }^{3)}$ mugianto@stkippgritulungagung.ac.id \\ ${ }^{1,2,3)}$ STKIP PGRI Tulungagung
}

\begin{abstract}
Abstrak
Untuk mengetahui perbedaan dari hasil belajar melalui penerapan model pembelajaran kooperatif tipe TGT, NHT dan pembelajaran langsung Direct Instruction, maka berdasarkan analisis data yang diperoleh yaitu terdapat perbedaan hasil belajar dengan menggunakan model pembelajaran NHT, TGT dan D.I. Hal ini dibuktikan dari hasil perhitungan ketiga metode dengan uji ANOVA didapat $F_{\text {obs }}$ $=22,14 ;$ selanjutnya $F_{\text {obs }}$ dibandingkan dengan $F_{\alpha ;(k-1, N-k)=2,87}(F$ tabel) dengan $\alpha=5 \%$ didapat $F$ tabel = 3,10 sehingga $F_{\text {obs }}=22,14 \in D K$ dengan $D K=\{F \mid F>3,10\}$ dan keputusan uji F-test adalah $H_{0}$ ditolak. Kemudian hasil analisis dengan menggunakan uji komparasi ganda diperoleh Taraf uji 5\% dengan DK=6,2 didapat $F_{1-2}=4,59<F_{\text {tabel }}=6,2$ berarti $H_{0}$ diterima; $F_{2-3}=8,21>F_{\text {tabel }}=6,2$, berarti $H_{0}$ ditolak; $F_{1-3}=25,09>F_{\text {tabel }}=6,2$, berarti $H_{0}$ ditolak. Dan dengan perolehan nilai rata-rata $T G T=86, N H T=75$, Direct Instruction $=60,3$. Jadi dapat disimpulkan TGT sama baiknya dengan NHT; TGT lebih baik dari Direct Instruction; NHT lebih baik dari Direct Instruction.
\end{abstract}

Kata kunci : Hasil Belajar, Team Game Tournament, Number Head Together, Direct Instruction.

\section{PENDAHULUAN}

Pendidikan adalah suatu kebutuhan yang wajib dipenuhi dalam kehidupan. Untuk meningkatkan kualitas sumber daya manusia harus melalui proses pendidikan yang baik dan terarah. Pendidikan merupakan kegiatan yang dapat dipandang sebagai pencetak sumber daya manusia yang kreatif dan inovatif (Sanjaya, 2006: 2).

Di dalam undang-undang No. 20 Tahun 2003 pasal 1 ayat 1 tentang Sistem Pendidikan Nasional menyatakan bahwa:

"Pendidikan adalah usaha sadar dan terencana untuk mewujudkan suasana belajar dan proses pembelajaran agar peserta didik secara aktif mengembangkan potensi dirinya untuk memiliki kekuatan spiritual keagamaan, pengendalian diri, kepribadian, kecerdasan, akhlak mulia, serta kemampuan yang diperlukan dirinya, masyarakat, bangsa dan Negara".

Berdasarkan uraian tersebut, pendidikan di sekolah bukanlah proses yang dilakukan secara asal-asalan, akan tetapi proses yang bertujuan sehingga segala sesuatu yang dilakukan guru dan siswa diarahkan pada pencapaian tujuan yang diharapkan.
Menurut Sanjaya "Salah satu permasalahan yang dihadapi pendidikan di Indonesia saat ini adalah lemahnya proses pembelajaran". Hal ini dapat dilihat dari hasil belajar siswa khususnya matematika sangat memprihatinkan karena jauh dari target yang diharapkan lantaran matematika terasa sulit karena banyak guru yang mengajar dengan cara penyampaian yang monoton, dan lebih sering duduk di kursi sambil menerangkan. Dari beberapa permasalahan tersebut maka di butuhkan kreativitas dari seorang guru untuk memperbaiki kinerjanya.

Berdasarkan observasi dan wawancara penulis kepada salah satu guru mata pelajaran matematika kelas VIII di SMPN 1 Kedungwaru, diketahui hasil belajar matematika siswa kelas VIII masih rendah. saat ini proses pembelajaran di SMP Negeri 1 Kedungwaru masih menggunakan pembelajaran langsung Direct Instruction. Menurut Sanjaya, Pembelajaran Direct Instruction yaitu dimana siswa lebih banyak belajar secara individu dengan hanya menerima, mencatat, dan menghafal materi pelajaran. Pada pembelajaran ini suasana kelas cenderung teacher-centered sehingga siswa menjadi pasif (Trianto, 2009: 6). Dengan 
demikian interaksi antara guru dengan siswa masih belum maksimal.

Menurut "Sanjaya "Salah satu permasalahan yang dihadapi pendidikan di Indonesia saat ini adalah lemahnya proses pembelajaran". Hal ini dapat dilihat dari hasil belajar siswa khususnya matematika sangat memprihatinkan karena jauh dari target yang diharapkan lantaran matematika terasa sulit karena banyak guru yang mengajar dengan cara penyampaian yang monoton, dan lebih sering duduk di kursi sambil menerangkan. Dari beberapa permasalahan tersebut maka di butuhkan kreativitas dari seorang guru untuk memperbaiki kinerjanya. Kreatifitas dapat dilakukan dengan pemilihan berbagai strategi, metode, model, maupun media pembelajaran (Listiawan, 2016), dengan berbagai setting termasuk pemanfaatan berbagai teknologi (Listiawan, 2015).

Menurut Arikunto ( 2010: 77) pengertian "Hasil belajar adalah hasil yang dicapai seseorang setelah melakukan kegiatan belajar dan merupakan penilaian seseorang untuk mengetahui sejauh mana materi yang sudah diterima”. Pendapat lain dari Sukiman (2011: 43) menyimpulkan "hasil belajar merupakan akibat dari adanya evaluasi belajar dan evaluasi belajar dilakukan untuk mengetahui kemampuan yang telah dicapai siswa setelah menerima pelajaran, evaluasi belajar ini berupa tes".

Dari beberapa pendapat tersebut dapat disimpulkan bahwa hasil belajar matematika adalah hasil yang dicapai seseorang setelah seseorang melakukan kegiatan belajar yang ditunjukan dengan hasil evaluasi belajar, yang berupa tes untuk mengetahui kemampuan yang telah dicapai siswa setelah menerima pelajaran matematika.

Terdapat beberapa faktor yang mempengaruhi hasil belajar. Faktor-faktor yang mempengaruhi hasil belajar siswa, yaitu:

1) Faktor Internal

a) Kesehatan

Kesehatan jasmani dan rohani sangat besar pengaruhnya terhadap kemampuan belajar. Bila seseorang tidak sehat dapat mengakibatkan tidak bergairah untuk belajar.

b) Intelegensi dan Bakat

Seseorang yang memiliki intelegensi baik, umumnya mudah belajar dan hasilnyapun cenderung baik. Sebaliknya, orang yang intelegensinya rendah, cenderung mengalami kesukaran dalam belajar, lambat berfikir sehingga prestasi belajarnyapun rendah.

c) Minat dan Motivasi

Minat dapat timbul karena adanya daya tarik dari luar ataupun datang dari hati sanubari. Minat yang besar terhadap sesuatu merupakan modal besar artinya untuk mencapai tujuan yang diamati itu. Timbulnya minat belajar disebabkan berbagai hal, antara lain karena keinginan yang kuat untuk menaikkan martabat atau memperoleh pekerjaan yang baik.

Motivasi berbeda dengan minat, motivasi adalah daya penggerak atau pendorong untuk melakukan suatu pekerjaan yang bisa berasal dari dalam diri atau dari luar.

2) Faktor Eksternal

Proses belajar didorong oleh motivasi intrinsik siswa. Di samping itu proses belajar juga terjadi, bila didorong oleh lingkungan siswa. Dengan kata lain aktivitas belajar dapat meningkat bila program pembelajaran disusun dengan baik. Penjabarkan faktor- faktor eksternal belajar sebagai berikut.

a) Guru Sebagai Pembina Siswa Belajar

Guru adalah pengajar yang mendidik. Ia tidak hanya mengajar bidang studi yang sesuai dengan keahliannya, tetapi juga menjadi pendidik generasi muda bangsanya. Sebagai pendidik, ia memusatkan kepribadian pada kepribadian siswa, khususnya berkenaan dengan kebangkitan belajar.

b) Prasarana dan Sarana Pembelajaran

Prasarana pembelajaran meliputi gedung sekolah, ruang belajar, lapangan olahraga, ruang ibadah, ruang kesenian, dan peralatan olahraga. Sarana 
pembelajaran meliputi buku pelajaran, buku bacaan, alat dan fasilitas laboratorium sekolah. Dan berbagai media pengajaran lain. Lengkapnya prasarana dan sarana pembelajaran merupakan kondisi pembelajaran yang baik.

c) Kurikulum Sekolah

Program pembelajaran di sekolah berdasarkan pada suatu kurikulum. Kurikulum yang diberlakukan di sekolah adalah kurikulum nasional yang disahkan oleh pemerintah, atau kurikulum yang disahkan oleh suatu yayasan pendidikan Kurikulum sekolah tersebut berisi tujuan pendidikan, isi pendidikan, kegiatan belajar mengajar, dan evaluasi. Berdasarkan kurikulum tersebut guru menyusun desain instruksional untuk pembelajarkan siswa. Hal itu berarti bahwa program pembelajaran di sekolah sesuai dengan sistem pendidikan nasional.

Menurut Slavin (2010: 163), model pembelajaran kooperatif tipe $T G T$ adalah salah satu tipe atau model pembelajaran kooperatif yang mudah diterapkan, melibatkan aktifitas seluruh siswa, melibatkan peran siswa sebagai tutor sebaya dan mengandung permainan dan bertukar informasi.

TGT menggunakan turnamen akademik, dan menggunakan kuis-kuis dan sistem skor kemajuan individual, di mana siswa berlomba sebagai wakil tim mereka dengan anggota tim lain untuk memperoleh skor tertinggi. Jadi, Model pembelajaran TGT merupakan model pembelajaran yang menitikberatkan belajar dengan kelompok dan mengerjakan tugas yang diberikan oleh guru secara bersama-sama. Siswa akan lebih aktif dalam pembelajaran, karena akan dituntut tanggung jawab setiap individu dan tanggung jawab kelompok akan mengikuti game pada akhir pokok bahasan pembelajaran.

Numbered Head Together (NHT) merupakan jenis pembelajaran kooperatif yang dirancang untuk mempengaruhi pola interaksi siswa, dan untuk menanamkan rasa tanggung jawab siswa dalam menelaah materi yang diajarkan. Teknik ini biasa digunakan dalam semua mata pelajaran, dan untuk semua tingkatan usia siswa. Menurut Anita (2010: 59) "Ciri pembelajaran Numbered Head Together ini adalah di mana guru akan mengajukan pertanyaan kepada seluruh kelas, yang kemudian akan diselesaikan bersama oleh siswa dalam kelompok kecil yang beranggotakan 3-5 orang".

Model pembelajaran Direct Instruction atau yang dikenal dengan model pengajaran langsung adalah salah satu pendekatan mengajar yang dirancang khusus untuk menunjang proses belajar mengajar peserta didik yang berkaitan dengan pengetahuan yang dapat diajarkan dengan pola kegiatan yang bertahap, selangkah demi selangkah.

Penelitian ini adalah penelitian eksperimen yang khusus dirancang guna mengetahui perbedaan model pembelajaran dengan menggunakan model pembelajaran kooperatif tipe TGT, NHT dan model pembelajaran langsung Direct Instruction dalam pelajaran matematika terhadap hasil belajar siswa yang dicapai. Kiranya dengan pengunaan model pembelajaran ini dapat meningkatkan pola berpikir siswa dalam kegiatan belajar mengajar didalam kelas dan berdampak pada peningkatan hasil belajar siswa karena dengan menerapkan model pembelajaran ini siswa akan termotivasi untuk dapat menemukan generalisasi dan memahami benar materi yang disampaikan oleh guru. Sehingga akan membangkitkan rasa ingin tahu untuk menemukan sendiri jawaban dari suatu soal yang diberikan. Dengan demikian siswa akan merasa senang, termotivasi, tertarik dan bersikap positif terhadap pembelajaran matematika. Akhirnya minat siswa untuk mengetahui lebih dalam tentang matematika akan semakin besar dan diharapkan hasil belajar akan meningkat.

Berdasarkan pada permasalahan di atas, maka tujuan penelitian ini adalah untuk mengetahui:

1. Ada tidaknya perbedaan hasil belajar matematika siswa yang diajar dengan model pembelajaran kooperatif tipe Team Games Tournament (TGT) dengan siswa 
yang diajar menggunakan model pembelajaran Numbered Head Together (NHT).

2. Ada tidaknya perbedaan hasil belajar matematika siswa yang diajar dengan model pembelajaran kooperatif tipe Numbered Head Together (NHT) dengan siswa yang diajar menggunakan model pembelajaran lansung Direct Instruction.

3. Ada tidaknya perbedaan hasil belajar matematika siswa yang diajar dengan model pembelajaran kooperatif tipe Team Games Tournament (TGT) dengan siswa yang diajar menggunakan model pembelajaran lansung Direct Instruction.

\section{METODE}

Penelitian yang dilaksanakan di UPTD SMP Negeri 1 Kedungwaru Tulungagung Tahun Pelajaran 2015/2016 ini meliputi 90 siswa sebagai sampel yang terbagi menjadi 3 kelompok kelas yaitu kelas VIII H terdiri dari 30 siswa sebagai kelas eksperimen 1, kelas VIII I terdiri dari 30 siswa sebagai kelas eksperimen 2, kelas VIII J terdiri dari 30 siswa sebagai kelas eksperimen 3. Penelitian dilakukan untuk menguji adanya perbedaan hasil belajar yang signifikan antara metode team games tournaments dengan metode number head together materi lingkaran pada siswa kelas VIII SMPN 1 Kedungwaru Tulungagung Tahun Pelajaran 2015/2016. Adanya perbedaan dapat dibuktikan dengan menggunakan uji ANOVA (Analysis of Variance) yang akan dibandingkan dengan nilai tabel $\mathrm{F}$, sehingga mampu menjawab hipotesis dengan membuktikan ada atau tidaknya perbedaan hasil belajar yang signifikan. Data tentang hasil belajar pada materi lingkaran yang diperoleh melalui teknik tes tertulis, setelah dilakukan suatu pembelajaran yang dibedakan antara kelas eksperimen 1, kelas eksperimen 2 dan kelas eksperimen 3, yang menggunakan metode metode kooperatif tipe TGT, NHT dengan metode pembelajaran langsung Direct Instruction. Data tes hasil belajar siswa yang disajikan adalah data yang didapat peneliti dari hasil pembelajaran akhir berupa tes.
Penelitian ini menggunakan The Randomized Control Group Posttests Design. Untuk mengetahui ada atau tidaknya perbedaan antara kelas eksperimen 1, eksperimen 2 dan eksperimen 3 dilakukan dengan hasil posttests (Sanjaya, 2013: 105). Ketiga kelas yang menjadi sampel diberikan perlakuan yang berbeda. Kelas eksperimen satu diberikan perlakuan pembelajaran menggunakan model pembelajaran kooperatif tipe $T G T$, kelas eksperimen dua diberikan perlakuan pembelajaran menggunakan model pembelajaran kooperatif tipe $N H T$ dan kelas eksperimen 3 diberikan perlakuan dengan pembelajaran langsung Direct Instruction.

Adapun teknik sampling yang digunakan dalam penelitian ini adalah Cluster random Sampling. Menurut Sugiyono (2015: 124) "cluster random sampling merupakan teknik sampling daerah digunakan untuk menentukan sampel bila objek yang akan diteliti atau sumber data sangat luas".

Dalam penelitian ini pengambilan sampel pada kelas VIII H, I, J. Pengambilan cluster random sampling yang dilakukan peneliti adalah sebagai berikut:

a. Pada 3 kelas tersebut mendapatkan pencapaian materi sesuai kurikulum yang sama

b. 3 kelas tersebut cenderung memiliki nilai rata-rata kelas yang hampir sama (dilihat dari rata-rata nilai rapor matematika).

c. Mendapatkan waktu pembelajaran yang sama dan guru yang mengajarpun sama. Berdasarkan data dan pertimbangan yang diperoleh akan mewakili populasi.

Untuk mengetahui perbedaan hasil belajar melalui penerapan model pembelajaran kooperatif tipe $T G T$, tipe NHT dan pembelajaran langsung Direct Instruction maka pada penelitian ini akan diukur dengan alat ukur yang sama. Hasil pengukuran tersebut akan digunakan sebagai data sampel, yang kemudian dianalisis dengan teknik statistika untuk menguji hipotesis yang telah ditetapkan. Berdasarkan langkah-langkah tersebut, maka penelitian ini termasuk penelitian dengan metode kuantitatif. Oleh karena itu dalam penelitian ini dapat 
diidentifikasikan menjadi dua variabel penelitian, yaitu:

1. Variabel dependent ( variabel terikat ), yaitu variabel yang dipengaruhi atau yang menjadi akibat karena adanya variabel independent. Dalam penelitian ini yang menjadi variabel terikat (Y) adalah hasil belajar matematika pada siswa yang berupa hasil belajar siswa pada materi lingkaran.

2. Variabel independent (variabel bebas) adalah variabel yang menjadi sebab atau yang mempengaruhi timbulnya atau berubahnya variabel dependent. Yang menjadi Variabel bebas (X) pada penelitian ini adalah metode pembelajaran. Dengan metode tipe team games tournaments sebagai $\left(X_{1}\right)$, metode numbered head together sebagai $\left(X_{2}\right)$ dan metode pembelajaran langsung direct instruction sebagai $\left(X_{3}\right)$.

\section{HASIL DAN PEMBAHASAN}

Berdasarkan uji validitas isi diperoleh hasil bahwa berdasarkan penilaian dari guru SMPN 1 Kedungwaru Tulungagung yaitu Bapak Sutoyo, S.Pd, M.M dan Bapak Nursalim, S.Pd menyatakan validitas isi dari instrumen penelitian yang berupa tes yang terbentuk uraian sejumlah 5 butir soal telah dipenuhi karena adanya kesesuaian atau kecocokan antara instrumen tes hasil belajar dengan kisi-kisi dan kartu soal materi lingkaran.

Untuk menguji reliabilitas dari instrumen yang berbentuk soal uraian sejumlah 5 butir soal, dalam penelitian ini menggunakan rumus Alpha. Uji coba instrumen tes hasil belajar dilakukan dikelas VIII A yang berjumlah 30 siswa.

$$
r_{11}=\left(\frac{k}{k-1}\right)\left(1-\frac{\sum{\sigma_{b}}^{2}}{\sigma_{t}{ }^{2}}\right)
$$

Keterangan :

$r_{11} \quad=$ Reliabilitas tes

$\mathrm{K}=$ Banyaknya butir soal

$\sum \sigma_{b}^{2}=$ Jumlah varian skor tiap-tiap butir soal

$\sigma_{t}^{2}=$ Varian total

(Arikunto, 2010: 239)
Berdasarkan perhitungan, diperoleh harga $r_{11}=0,80$. Sedangkan ketentuannya, soal dikatakan memiliki reliabilitas tinggi jika nilai $r_{11}$ lebih dari 0,70 . Ternyata dari hasil perhitungan didapat nilai $r_{11}$ lebih dari 0,70 maka soal tes tersebut memiliki reliabilitas tinggi atau reliabel.

Pada penelitian ini uji hipotesisnya dengan menggunakan uji $F$-test menggunakan ANOVA (Analysis of Variance) satu jalan dengan sel tak sama untuk mencari perbedaan dari ketiga metode, setelah itu dilanjutkan dengan menggunakan uji komparasi ganda dengan metode scheffe' untuk melihat dari ketiga metode tersebut manakah yang lebih baik.

Sebelum dilakukan uji analisis ada beberapa persyaratan yang harus dipenuhi, yaitu data harus berasal dari populasi yang berdistribusi normal dan homogen. Dari perhitungan uji normalitas dan uji homogenitas menunjukkan bahwa ketiga kelas berdistribusi normal dan tidak ada perbedaan atau ketiga kelas tersebut homogen. Serta dapat ditunjukkan dengan uji anova diperoleh $\mathrm{F}_{\mathrm{obs}}=$ 22,14 dan $F_{\text {tabel }}=3,10$. Karena $F_{\text {obs }}>F_{\text {tabel }}$ berarti $\mathrm{H}_{0}$ ditolak dan $\mathrm{H}_{1}$ diterima. Karena $\mathrm{H}_{0}$ ditolak maka kesimpulannya terdapat perbedaan hasil belajar antara siswa yang mendapat pembelajaran kooperatif tipe $T G T$, NHT, dan pembelajaran langsung Direct Instruction dengan materi lingkaran pada siswa kelas VIII SMPN 1 Kedungwaru Tulungagung.

Kemudian dilanjutkan dengan menggunakan uji komparasi ganda dengan metode Scheffe' untuk melihat perbedaan antara ketiga metode pembelajaran tersebut:

1. $F_{1-2}=4,59<F_{\text {tabel }}=6,2$. Karena $F_{\text {obs }}<F_{\text {tabel, }}$ yang berarti $\mathrm{H}_{0}$ diterima maka dapat dikatakan bahwa hasil belajar dengan menggunakan metode pembelajaran kooperatif tipe $T G T$ sama baiknya dengan kooperatif tipe $N H T$.

2. $F_{2-3}=8,21>F_{\text {tabel }}=6,2$. Karena $F_{\text {obs }}>F_{\text {tabel, }}$ yang berarti $\mathrm{H}_{0}$ ditolak maka dapat dikatakan bahwa hasil belajar dengan menggunakan metode pembelajaran kooperatif tipe $N H T$ lebih baik dari pada 
metode pembelajaran langsung Direct Instruction.

3. $\mathrm{F}_{1-3}=25,09>\mathrm{F}_{\text {tabel }}=6,2$. Karena $\mathrm{F}_{\mathrm{obs}}>$ $\mathrm{F}_{\text {tabel, }}$ yang berarti $\mathrm{H}_{0}$ ditolak maka dapat dikatakan bahwa hasil belajar dengan menggunakan metode pembelajaran kooperatif tipe $T G T$ lebih baik dari pada metode pembelajaran langsung Direct Instruction.

Sedangkan dilihat dari nilai rata-rata hasil belajar, kelas eksperimen 1 yang di beri perlakuan dengan metode kooperatif tipe $T G T$ yaitu 86 dan kelas eksperimen 2 yang di beri perlakuan dengan metode kooperatif tipe $N H T$ yaitu 75 juga lebih baik dibandingkan dengan kelas eksperimen 3 yang di beri perlakuan dengan metode pembelajaran langsung Direct Instruction yaitu 60,3 dengan materi lingkaran siswa kelas VIII SMPN 1 Kedungwaru Tulungagung Tahun Pelajaran 2015/2016.

Dari hasil penelitian dapat disimpulkan bahwa pembelajaran dengan menggunakan metode kooperatif tipe $T G T$ sama baiknya dengan model pembelajaran NHT; model pembelajaran $T G T$ lebih baik dari model pembelajaran Direct Instruction; model pembelajaran NHT lebih baik dari model pembelajaran Direct Instruction.

Berdasarkan kenyataan di lapangan yang terlihat selama penelitian pada kelas eksperimen 1 yang dikenakan model pembelajaran kooperatif $T G T$ menunjukkan bahwa siswa menjadi lebih aktif saat pembelajaran berlangsung. Siswa tidak hanya mendengarkan penjelasan guru, tetapi lebih aktif berdiskusi dalam kelompoknya karena setiap siswa merasa mempunyai tanggungjawab terhadap kelompoknya masingmasing. Hal ini sependapat dengan (Slavin, 2010: 61) yang menyatakan, bahwa dalam pembelajaran kooperatif siswa dapat lebih menemukan dan memahami konsep-konsep yang sulit melalui diskusi. Pembagian kelompok secara heterogen memberikan kesempatan kepada siswa untuk saling membantu dalam memahami konsep pelajaran. Siswa yang mempunyai tingkat penguasaan materi yang lebih baik dapat memberikan pemahaman bagi siswa lain dalam kelompoknya sehingga semua anggota kelompoknya dapat menguasai materi dengan baik. Pembelajaran disini akan lebih menyenangkan karena adanya game dan Tournaments. Adanya sebuah kompetisi dalam proses pembelajaran yang semua siswa sudah pasti akan mengikuti kompetisi tersebut, maka akan memacu siswa untuk lebih bertanggung jawab dan memahami materi lebih dalam.

Suasana pembelajaran didalam kelas eksperimen 2 yang dikenakan model pembelajaran kooperatif tipe $N H T$ yaitu model pembelajaran ini memberikan kesempatan kepada siswa untuk saling membagikan ide-ide dan mempertimbangkan jawaban yang paling tepat. Selain itu, model pembelajaran ini juga mendorong siswa untuk meningkatkan semangat kerjasama mereka. Karena guru akan memanggil salah satu nomor dari setiap kelompok, maka setiap kelompok dalam NHT harus memahami dan mengetahui materi yang diberikan. Siswa terlibat aktif dalam pembelajaran, meskipun dijumpai juga siswa yang tidak mau berdiskusi di dalam kelompoknya. Dikarenakan rasa tanggung jawab siswa untuk memahami materi dalam pembelajaran NHT lebih sedikit, karena tidak pasti setiap siswa berpeluang untuk menjawab pertanyaan.

Sedangkan suasana pembelajaran didalam kelas eksperimen 3 yang dikenakan model pembelajaran langsung Direct Instruction pada pembelajaran ini siswa kurang antusias dan terkesan malas, ramai sendiri dan rasa terpacu mereka untuk menyelesaikan masalah juga sedikit, karena model pembelajaran ini menggunakan metode ceramah. Dalam menyelesaikan masalah siswa juga membutuhkan waktu yang cukup lama hal ini disebabkan siswa berpikir secara individu.

\section{KESIMPULAN}

Menjawab rumusan masalah tentang perbedaan hasil belajar matematika siswa yang diajar dengan model pembelajaran kooperatif tipe Team Games Tournament (TGT) , Numbered Head Together (NHT) dengan Direct Instruction, maka hasil yang didapat dari analisis data adalah Dari tabel uji ANOVA 
diatas Berdasarkan hasil perhitungan dengan menggunakan $F_{o b s}=0,294$; selanjutnya $F_{o b s}$ dibandingkan dengan $\mathrm{F}_{\alpha ;(\mathrm{k}-1, \mathrm{~N}-\mathrm{k})=2,78}(\mathrm{~F}$ tabel $)$ dengan $\alpha=5 \%$ didapat $\mathrm{F}$ tabel $=3,113$ sehingga $F_{o b s}=0,294 \in \mathrm{DK}$ dengan $\mathrm{DK}=$ $\{F \mid F>3,113\}$ dan keputusan uji $F$-test adalah $\mathrm{H}_{0}$ ditolak dan berarti $\mathrm{H}_{1}$ diterima. Jadi dapat disimpulkan bahwa ada perbedaan hasil belajar yang signifikan antara metode pembelajaran team game tournament, number heads together dan direct instruction pada materi lingkaran siswa kelas VIII SMPN 1 Kedungwaru Tahun Pelajaran 2015/2016.

Hal ini berarti penelitian ini berhasil, hasil belajar dengan menggunakan metode Pembelajaran Team Games Tournament ( TGT ) lebih baik daripada menggunakan metode Number Heads Tougether (NHT) metode pembelajaran langsung (Direct Instruction) pada materi pokok lingkaran siswa kelas VIII SMPN 1 Kedungwaru Tahun Pelajaran 2015/2016. Hal ini dapat disimpulkan bahwa terdapat pengeruh metode pembelajaran TGT ,NHT dengan Direct Instruction terhadap hasil belajar siswa. Terdapat perbedaan hasil belajar matematika pada siswa yang diterapkan model pembelajaran kooperatif tipe Team Game Tournament, Number Heads Together dan dengan metode pembelajaran langsung Direct Instruction pada siswa kelas VIII SMP Negeri 1 Kedungwaru Tahun Pelajaran 2015/2016, diduga hasil belajar siswa dengan menggunakan model pembelajaran kooperatif tipe Team Game Tournament lebih baik dibandingkan model pembelajaran kooperatif tipe Number Heads Together dan metode pembelajaran langsung Direct Instruction.

Perbedaan pengaruh penggunaan kooperatif tipe Team Game Tournament lebih baik dibandingkan model pembelajaran kooperatif tipe Number Heads Together dan metode pembelajaran langsung Direct Instruction. Dari ketiga metode tersebut membuktikan bahwa kooperatif tipe Team Game Tournament terbukti lebih baik dalam hasil belajar.

\section{DAFTAR RUJUKAN}

Arikunto, suharsimi. 2010. Prosedur Penelitian Suatu Pendekatan Praktik. Jakarta: Rineka Cipta.

Budiningsih, asri. 2004. Belajar dan Pembelajaran. Jakarta: PT Rineka Cipta.

Dalyono,M.2007. Psikologi Pendidikan. Jakarta:RinekaCipta.

Dini, Rahmawati. 2011. Eksperimentasi Model Pembelajaran Kooperatif Tipe Teams Game Tournament dan Number Head Together Pada Materi Pokok Sistem Persamaan Linier Dua Variabel Ditinjau dari Aktivitas Belajar Siswa SMP Negeri 5 Tulungagung Tahun Pelajaran 2011/2012.

Slavin, Robert E. 2010. Cooperatif Learning. Bandung: Nusa Media.

Hamalik,Oemar.2010. Perencanaan Pengajaran Berdasarkan Pendekatan Sistem. Jakarta: PT Bumi Aksara

Hudojo, Herman. 2005. Pengembangan Kurikulum dan Pembelajaran Matematika .Malang: Uneversitas Negeri Malang.

Hudojo, Herman. 1990. Srategi Mengajar Belajar Matematika. Malang: IKIP.

Lestari, ayu. 2011. Perbandingan Hasil Belajar Menggunakan Model Pembelajaran Kooperatif Tipe Team Games Tournament dan Kooperatif Tipe Number Head Together di SMKN 2 Boyolangu Tahun Pelajaran 2011/2012.

Lie, Anita. 2010. Cooperative Learning. Jakarta:Grasindo.

Listiawan, Tomi. 2015. Analisis Technological Content Knowledge (TCK) Calon Guru Matematika Dalam Menggunakan Perangkat Lunak Geometri Dinamis. Disajikan pada seminar nasional matematika dan pendidikan matematika UNY 2015.

Listiawan, Tomi. 2016. Pengembangan Learning Management System (LMS) di Program Studi Pendidikan Matematika STKIP PGRI Tulungagung. Jurnal Ilmiah Penelitian dan Pembelajaran Informatika (JIPI).1(01). 
Nohan, khoirul. 2012. Perbedaan Hasil Belajar Matematika Antara Siswa yang Diajar dengan Model Pembelajaran Kooperatif Tipe Team Games Tournamen (TGT) dan Konvensional pada Siswa Kelas VII UPTD SMP Negeri 2 Sumbergempol dengan Materi Pokok Segitiga dan Segi empat Tahun Ajaran 2012/2013. Skripsi tidak dipublikasikan. Tulungagung: STKIP PGRI Tulungagung. Nurul, hayati. 2006. Model Pembelajaran. Jakarta: Rineka Cipta.

Purwanto, M.ngalim. 2010. Prinsip-Prinsip dan Teknik Evaluasi Pengajaran. Bandung: PT Remaja Rosdakarya.

Rusman. 2011. Model - Model Pembelajaran: Mengembangkan Profesionalisme Guru. Jakarta: Rajawali Pers.

Sanjaya, wina. 2006. Strategi Pembelajaran: Berorientasi Standar Proses Pendidikan. Jakarta: Kencana.

Soejadi, R.1999. Kiat Pendidikan Matematika di Indonesia. Jakarta: Drektorat Jenderal Pendidikan Tinggi.
Suherman, Erman.dkk. 2003.Strategi Pembelajaran Matematika Kontemporer. Jakarta : UPI Press.

Suprijono, Agus. 2009. Cooperatif Leraning.Yogyakarta: PustakaPelajar.

Sukiman. 2011. Pengembangan Sistem Evaluasi. Yogyakarta: InsanMadani.

Sugiarto, Tri. Perbedaan Hasil Belajar Matematika Antara Siswa yang Diajar dengan Menggunakan Model Pembelajaran Kooperatif Tipe NHT (Number Head Together) dan Model Pembelajaran Konvensional Kelas VIII di SMP Negeri 3 Tulungagung Tahun Ajaran 2012/2013. Skripsi tidak dipublikasikan. Tulungagung: STKIP PGRI Tulungagung.

Sudjana, nana. 2010. Penilaian Hasil Proses Belajar Mengajar. Bandung: PT Remaja Rosdakarya.

Trianto. 2009. Model - model Pembelajaran Inovatif Berorentasi Konstrutivistik. Jakarta: Prestasi Pustaka.

Usman, Uzer Moh.2011. Menjadi Guru Profesional. Bandung: Remaja Rosdakarya. 